\title{
Migration Crises and the Principle of Solidarity in Times of Sovereignism: Challenges for EU Law and Polity
}

\section{1 \\ Introduction: the Implementation of the Principle of Solidarity as} a 'Make-it or Break-it' Challenge for the $\mathrm{EU}^{1}$

\subsection{Does the European Integration Process Postulate Solidarity?}

This special issue aims at addressing the crisis of solidarity which is hammering the governance of irregular migration and asylum policies within the EU. ${ }^{2}$

The Treaties expressly mention the pivotal role of the principle of solidarity in the EU integration process, as one finds in Articles 2 and 3 of the TEU, where solidarity is among the fundamental values of the EU. To be more precise, solidarity is also one of the founding principles of the internal market, which aims at achieving a social market economy, realizing solidarity between generations and among Member States. ${ }^{3}$

In the field of migration and asylum law, solidarity between Member States is a core element of the common policies on asylum, immigration and external border controls, together with fairness toward third-country nationals. ${ }^{4}$ For example, Article 80 TFEU mirrors the concern about solidarity by stating that migration policies shall be "governed by the principle of solidarity and fair sharing of responsibility". ${ }^{5}$ Moreover, in his Opinion in the case Slovakia and

1 Before the German Parliament, Angela Merkel stated: "Europe faces many challenges, but that of migration could become the make-or-break one for the EU." Source: Reuters, Migration challenge is make-or-break for EU, says passionate Merkel, on 28.6.2018, at https:// www.reuters.com/article/us-europe-migrants-merkel/migration-challenge-is-make-or -break-for-eu-says-merkel-idUSKBNiJOoTO [last access: 5.12.2019].

2 Takle, M. (2018) Is the migration crisis a solidarity crisis?, in: A. Grimmel (Ed), The Crisis of the European Union, London: Routledge, pp. 116-129.

3 See Witte, F. de, (2015) Justice in the EU: the Emergence of Transnational Solidarity, Oxford: Oxford University Press; Sangiovanni A. (2013) Solidarity in the European Union, Oxford Journal of Legal Studies, pp. 1-29.

4 Article 67 TFEU.

5 Biondi A., Dagilytė, E., Küçük, E. (Eds) (2018), Solidarity in EU Law: Legal Principle in the Making, London: Edward Elgar; Karageorgiou, E. (2018) Rethinking solidarity in European asylum law: A critical reading of the key concept in contemporary refugee policy (thesis), Lund: Lund 
Hungary v. Council, ${ }^{6}$ Advocate General Bot stressed that "solidarity is among the cardinal values of the Union and is even among the foundations of the Union". According to Bot, "solidarity is both a pillar and at the same time a guiding principle of the European Union's policies on border checks, asylum and immigration".

Irrespective of its legal relevance, the principle of solidarity in the policies of migration and asylum is in a deep crisis. Attempts at enacting instruments translating forms of solidarity in the EU have created tensions and conflicts at many levels, between Member States (horizontal level) and between (some) states and the EU (vertical level).

This has happened although in political speeches solidarity is usually invoked as the 'binding element' the EU needs in order to show its capacity to 'throw the heart beyond the obstacle', motivating the exceptional pooling of resources in difficult times.

As a matter of fact, solidarity is needed to create momentum for reforms and actions to counterbalance the distortive effects of integration projects created upon incomplete political visions. For example, it is uncontested that the Eurozone and the euro have been built upon an incomplete post-national sovereign idea: on the one side, monetary union is seen as an exclusive competence of the EU, while, on the other, fiscal and economic policies are firmly left in the hands of the Member States. Because of this, the Eurozone has implied codification of structural asymmetries, creating injustices: some states could profit more than others from the euro; when these structural deficiencies have materialized in all their consequences, solidarity has been invoked to support actions restoring justice. ${ }^{7}$

In the governance of migration too, solidarity is invoked to support deep correction measures, addressing the structural disparities created by an incomplete political project.

University; Morano-Foadi S. (2017) Solidarity and Responsibility: Advancing Humanitarian Responses to EU Migratory Pressures, European Journal of Migration and Law, pp. 223-254, at 227; Moreno Lax, V. (2017) Solidarity's Reach: Meaning, dimensions and implications for EU (external) asylum policy, Maastricht Journal of European and Comparative Law, pp. 744 ff.; Tsourdi, E. (2017) Solidarity at work? The prevalence of emergency-driven solidarity in the administrative governance of the Common European Asylum System, Maastricht Journal of European and Comparative Law, pp. 667-686.

6 Opinion of Advocate General Bot, 26 July 2017, Cases C-643/15 and C-647/15, Slovak Republic, Hungary v. Council of the European Union, ECLI:EU:C:2017:618.

7 This happened in the context of the EMU, with the Treaty on the European Stability Mechanism (ESM) and the Fiscal Compact, which were adopted outside EU Treaties. 


\section{$2 \quad$ Why Is Solidarity in Asylum and Migration That Difficult to Achieve?}

For geographical and geopolitical reasons, migration does not affect European states in the same way, either as destinations or as transit countries. ${ }^{8}$ At the same time, cooperation in the context of the Schengen Agreement and the Dublin Convention was not thought of as an integration process based on solidarity, but rather as a set of rules to allocate responsibility for asylum applications, in an intergovernmental logic of cooperation.

The Commission is aware of that. The Commission itself has written that the Dublin system must be reformed, "both to simplify it and enhance its effectiveness in practice, and to be equal to the task of dealing with situations when Member States' asylum systems are faced with disproportionate pressure". ${ }^{9}$ In a nutshell, according to the Commission, the current Dublin system is unfair.

Alongside Dublin, whose 'first entrance' paradigm reinforces the structural disparities inherent in geography, there are other rules which make it more complex to reach solidarity and fair allocation of responsibility between Member States: e.g., the rule according to which all Member States are considered safe countries for third-country nationals, in spite of the structural differences existing within the EU. The early application of the principle of mutual trust exacerbated this problem. ${ }^{10}$

As a matter of fact, the governance of the humanitarian dimension of migration constitutes a complex and critical policy area of European integration, where states have divergent interests, the EU shares limited competence and integration does not progress. ${ }^{11}$ Solidarity within the EU, between Member States and toward third-country nationals entails complex redistributive questions on which states want to have full control, for several reasons: first, due to budgetary implications; second, because of the systemic trust these progresses

8 Goldner Lang, I. (2018) The EU financial and migration crises: two crises—many facets of EU solidarity, in: A. Biondi, E. Dagilytė, E. Küçük (Eds), Solidarity in EU Law: Legal Principle in the Making, London: Edward Elgar, pp. $133 \mathrm{ff}$.

9 Commission Communication of 4.5.2016, Proposal for a Regulation of the European Parliament and of the Council establishing the criteria and mechanisms for determining the Member State responsible for examining an application for international protection lodged in one of the Member States by a third-country national or a stateless person (recast), сом (2016) 270 final, on the so-called 'Dublin IV' proposal, p. 3.

10 Sílvia Morgades Gil's article examines precisely this issue.

11 Nicolosi, S. (2019) La riforma del sistema europeo comune di asilo tra impasse negoziale e miopia normativa, Rivista trimestrale di diritto pubblico, pp. $521 \mathrm{ff}$. 
require; ${ }^{12}$ third, solidarity in asylum means some openness toward non-European citizens on matters touching upon access to domestic welfare systems. The EU itself has limited supranational bureaucracies, perhaps with the exception of Frontex, now the European Border and Coast Guard Agency: in other words, the EU requires Member States to enforce EU law.

This is precisely the most crucial challenge underpinning the effort to achieve forms of solidarity among Member States. It is since the Treaty of Amsterdam, and precisely in the Tampere European Council Conclusions, of 1999, that solidarity has been indicated as a guiding principle in the establishment of the Common European Asylum System (CEAS).

Twenty years after Tampere, the picture is rather discomforting: Member States have different interests and few incentives to cooperate in facing the arrival of unprecedented numbers of migrants and organizing coordinated action. Some states (host and transit states) need the support of others, but others (non-host states) have very few incentives to cooperate. This could be a picture of the status quo, where we see EU Member States as characters of a theater of the absurd piece, who claim they want to make reforms, while most of them in reality can simply live with the status quo. Moreover, they can even dwell upon the structural imbalances reinforced by existing rules, since irregular migrants are not entitled to travel toward their territories and apply for asylum there. Alongside this, Member States can also invoke rules which allow a weakening of European integration, for example suspending Schengen, in law or simply de facto. Again, in their own interests, they can invoke the unbalance created by 'incomplete' rules.

\section{Intertwining European and Comparative Constitutional Perspectives of the Solidarity Crisis: the Innovative Approach of this Special Issue}

Against this backdrop, recent developments at the level of EU Member States signal the need to discuss the survival of EU migration policy in a time of political turmoil and sovereignty-based arguments in domestic and European politics. ${ }^{13}$ Indeed, Italy's 'closed ports policy', coupled with Malta's refusal to accept the Aquarius ship and the French President's reaction against Italian

12 Poiares Maduro, M. (2007) So close and yet so far: the paradoxes of mutual recognition, Journal of European Public Policy, pp. 814-825.

13 Lavenex, S. (2018) Failing Forward Towards Which Europe? Organized Hypocrisy in the Common European Asylum System, Journal of Common Market Studies, pp. 1195-1212. 
'immigration cynicism', raised again the issue of intra-European solidarity and responsibility sharing. On the very same days when Italy, Malta and Spain were discussing the destiny of the Aquarius, the Hungarian Parliament passed a constitutional amendment aiming at introducing the concept of constitutional self-identity. In doing so, the Hungarian Parliament was actually following up a previous judgment of the Hungarian Constitutional Court which recalled the concept of the "constitutional self-identity of Hungary", the preservation of which is a duty for all state bodies (art. 3, Bill T-332).

The failed attempt to thoroughly discuss and reform the Dublin system represents an additional sign of the political weakness of supranational institutions in addressing the establishment of a migration governance system which is fair and balanced and an expression of solidarity within the EU.

The weakness of the European asylum system can be seen as the mirror of the weakness of the entire European integration process. This is when the role of the principle of solidarity is brought into play: when effectively implemented and assumed by the Member States as part of their own constitutional identities - and thus, part of the "constitutional traditions common to the Member States" - it may act as a driving principle toward a more sustainable common and integrated European asylum system. The consequences may be appreciated not only in terms of efficient management but also in terms of effective protection of the fundamental rights of the individuals involved. Significantly enough, Advocate General Bot interpreted the opposition of the two recurring Member States-Slovakia and Hungary, together with the support of Poland - to the so-called relocation mechanism ${ }^{14}$ as the expression of "the crisis of the European integration project, which is to a large extent based on a requirement for solidarity between the Member States which have decided to take part in that project".

While many studies have covered migration crises and answers have come from the EU and Member States, there is still little literature on how a transnational/quasi-federal polity enforces solidarity values when it comes to external migration flows.

Against this backdrop, our approach is quite different and innovative as we address the issue of solidarity in EU migration policy by merging the European perspective, centered on EU measures, with a comparative constitutional perspective concerning the level of enforcement of the solidarity mechanism at the level of Member States as well as the anti-solidarity reactions of those

14 Introduced by the Council Decision (EU) 2015/1601 of 22 September 2015 (establishing provisional measures in the area of international protection for the benefit of Italy and Greece). 
Member States which have not complied with EU law to avoid full-fledged participation in the CEAS or out of fear of domestic political tensions. Moreover, our perspective entails comparison with federal systems facing migration and placed in a position that somehow mirrors the EU situation.

In more detail, we intend to contribute to the literature by doing the following: we firstly address how sovereignty-based arguments, translated into sovereignism, effectively act as a bulwark against implementation of the solidarity mechanism, and how this should be resolved. We then move on to an analysis of EU instruments to strengthen, incentivize or improve solidarity and cooperation in the field of asylum policy. In such a context, we also sketch out the scenario of the consequences of the lack of solidarity within the EU.

In addressing the interplay between $\mathrm{EU}$ rules and domestic implementation we specifically focus on the functioning of the so-called "safe third-country rule" (or STC rule) as it is one of the key drivers of current EU migration policy. The sTC rule is a good example of the interplay between the European and the Member State levels. Indeed, application of the STC rule is, at the same time, one of the issues Member States intend to center the discussion on, when addressing possible amendments to the Dublin System, ${ }^{15}$ and one of the legal tools that have proved to be crucial in the proper functioning of the system. On the basis of the STC rule, some state courts, including the Italian Council of State, have prevented transferal of asylum applicants to other EU countries (namely Hungary and Bulgaria), by stating that those countries provide wholly insufficient standards of human rights protection. ${ }^{16}$ In doing so, domestic judges have inadvertently inflamed the political climate both internally and externally, converting themselves into active and even proactive subjects of effective implementation and building of an effective CEAS.

Finally, our analysis is coupled with a comparison of the management of migration in federal contexts, such as Canada and the US. We deliberately selected these countries, out of other possible alternatives, because they are facing similar issues: Canada is a federal state dealing with a privileged partner, the US, which is recalcitrant to fully accept the responsibility sharing mechanism provided for in the US-Canada agreements.

By merging the European with the comparative constitutional perspective, we intend to link the problem of mass migration with the broader issue of the building of an authentic transnational polity, which should be able to speak with a single voice in immigration matters. Indeed, detaching the management

15 The proposal to amend the regulation on asylum procedures concerns the safe thirdcountry rule and its mandatory application for immigration judges.

16 Consiglio di Stato (Terza Sezione), 27 September 2016, n. 03999/2016 REG. PROV. COLL. 
of mass migration from the issue of building a transnational polity is probably one of the reasons of the current shortcomings of the asylum and border control policies.

This special issue thus aims at filling this gap. In our theoretical framework, the EU is a polity that mirrors some of the operational strategies of federal systems. When it comes to migration, asylum and border control though, state sovereignty is still a bulwark against genuine political integration. In other words, migration policy needs to be addressed in light of the perspective of European integration and thus by linking the application of European measures to the broader political context of Member States. What the migration crisis reveals is thus the tension between a sovereignty-based rhetoric and the concrete impossibility to face contemporary mass migration at domestic level.

By framing governance of migration fluxes in the context of European integration, with a twofold European and comparative constitutional perspective, this issue will contribute to the debate on the difficult emergence of effective forms and mechanisms of solidarity within the EU.

\section{Organization of the Special Issue}

The special issue starts with the contribution by Simone Penasa and Graziella Romeo, which introduces the issue of the interplay between states' sovereignties and the effective implementation of the common European asylum system. They work on two assumptions: on the one hand, the sovereignty-based argument finds its way because of the EU's weaknesses in terms of migration strategy; and, on the other hand, sovereignty arguments can (and must) be confronted with the legal instruments afforded by the existing framework of EU law. Accordingly, an in-depth analysis of the Italian dynamics in the context of migration management is functional to qualifying and assessing States' sovereigntist claims from the perspective of their compatibility with the essentials of constitutionalism; a distinction between a pre-constitutional idea of sovereignty and a fully constitutional understanding of national sovereignty, conceived as a power exercised in constant dialogue with the international community, is proposed. Then the two authors integrate a more EU-centric perspective with the national one, in order to test to what extent arguments based on sovereignty stand as a bulwark against full cooperation among EU member states. In this part, the article examines the legal instruments that EU institutions can use and develop to implement solidarity and reduce the margin for use of sovereignty-based arguments in immigration policies. Thus, they propose a three-fold possible qualification of State's sovereignty, which 
depends on its compatibility with EU law: enshrined, embraced and untenable sovereignty.

Romeo and Penasa's analysis is completed by the following contribution, which frames states' attitude within the broader context of the integration process. Indeed, Iris Goldner Lang's piece has a twofold aim. First, it highlights the ever-increasing phenomenon of Member States' infringements of EU migration and asylum law as an instance of the violation of the principle of solidarity, and then it discusses the reasons behind it. Goldner Lang suggests that EU inter-state solidarity is just as much about respecting EU law as it is about states helping each other, as the latter cannot subsist without the former. Second, she considers whether the existing mechanisms for reducing the number of violations are sufficient and discusses the new mechanisms that are being developed - particularly conditionality. Goldner Lang identifies two groups of reasons explaining the frequent violations of EU obligations. The first group is applicable to the whole of EU law, and the second one specifically to EU migration and asylum law. The author frames Member States' violations as a process of political withdrawal or retrenchment from certain parts of the commonly adopted EU migration and asylum law. She uses the notion of "spillback" or disintegration (as opposed to further European integration) and the concepts of "exit" and "voice" (conceived by Albert Hirschman and developed further by Joseph Weiler in his seminal work The Transformation of Europe) to frame the EU migration crisis in the broader context of the crisis of the integration process.

Luisa Marin's contribution "Waiting (and Paying) for Godot: Analyzing the Systemic Consequences of the Solidarity Crisis in EU Asylum Law" investigates on the consequences of the solidarity crisis for the $\mathrm{EU}$ as a governance system.

Relocation schemes tried to achieve intra-state solidarity across Member States in the aftermath of the 2015 crisis but did not prove to be successful, in light of overall low relocation rates, in addition to open contestation by the states of the Visegrad group.

Against the background of the stalemate of the reform of the Dublin Regulation, Marin's article analyzes 'measures' adopted after the failure of relocation schemes, focusing in particular on administrative arrangements to counter secondary movements and 'ad hoc' temporary disembarkation schemes. Both measures are aimed at fixing longstanding questions (e.g., limiting secondary movements and providing safe disembarkation for irregular migrants): in the first case, a state proceeds at bilateral level with arrangements creating fast-track returns and stopping secondary movements; in the second case, the EU is trying to support states' arrangements for disembarkation of migrants after SAR operations. 
The article shows that, while reforms of legislative instruments are not progressing, Member States and, to some extent, also EU institutions are going down the lane of 'operational and informal arrangements', which are 'bricolage solutions' to counter undesired effects of the status quo, while waiting for structural solutions that are necessary but not in sight.

The article reflects upon the dangers of this wave of administrative and informal operational solutions, as a challenge to the EU as a system of governance based on the rule of law.

With Sílvia Morgades Gil's article, "The 'Internal' Dimension of the Safe Country Concept", we get into one of the core issues of the Dublin asylum system as she addresses interpretation of the safe third-country rule by international and internal courts. The non-refoulement principle has been interpreted extensively as regards what kind of threats prevent removal to another country by resorting to international instruments for the protection of human rights. Nevertheless, this principle does not prohibit removal to a safe country. Thus, a system of shared responsibility may entail that refugees and asylum seekers are transferred from one country to another in order to try to obtain or to benefit from international protection. The academic literature has extensively addressed the meaning of the concept of the safe third country. Morgades Gil contributes to this literature by analyzing the application of the third-country concept within a system where all states are supposed to be safe for all asylum seekers, and the principle of mutual trust and equivalence of protection applies. The contribution reviews the safe-country concept in the context of the Dublin system and examines when and why international, European and internal courts and other institutions have considered that one of the states participating in the system was not safe ad intra. The author then discusses the impact that the analysis may have on the principle of mutual trust that is at the heart of the area of Freedom, Security and Justice.

Finally, Davide Strazzari's contribution broadens the scope of the analysis by approaching the US and Canadian cases with regard to resettlement policies, intended as selection and transfer of refugees from a state in which they have sought protection to a third state which has agreed, voluntarily, to admit them. As resettlement could be a legal way, and one more easily accepted (by states), to access for refugees in the EU context too, comparison with federal legal systems where this mechanism represents a well-grounded praxis contributes to highlighting pros and cons of it. Particularly relevant becomes the interplay with the principle of solidarity, in which the author distinguishes between an international and an intra-national dimension. The latter is further divided into a vertical dimension, which refers to the role of the subnational units with regard to selection and distribution of refugees across the country; 
and a horizontal one, which relates to the involvement of civil society in some elements of their identification or reception. Strazzari comes to the conclusion that, if resettlement is usually immune from current populist narratives that depict immigration as contrary to national interests, comparative analysis of the US and Canadian systems reveal that this assumption cannot be necessarily true, as the lack or insufficient involvement and coordination of both vertical and horizontal dimensions of intranational solidarity can cause strong resistances at local level and influence, in turn, the national political arena.

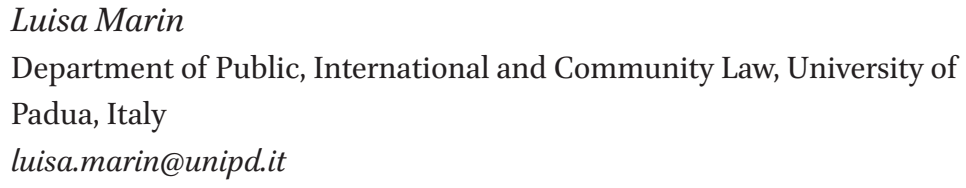

